\title{
Incorporation in the Siege of Melayne
}

\author{
Suzanne Conklin Akbari
}

In the debate concerning precisely what constitutes a medieval 'romance' the Siege of Melayne occupies a special position. As a number of readers have noted, this poem participates in the conventions both of romance (understood as a genre fundamentally concerned with the deeds of knights) and of hagiography. The focus of such cross-generic readings is usually the character of Archbishop Turpin who, as Barron puts it, has 'as much of the saint as of the soldier in his nature'. ${ }^{\text {I The cross- }}$ generic status of the Siege of Melayne is also in evidence in the dramatic scene which takes place in the chamber of the sultan Arabas, when a crucifix is cast by the Saracens into a great fire and, miraculously, does not burn. Elsewhere in the poem, too, as I will illustrate below, religious and even eucharistic imagery plays a vital role in the unfolding of the narrative. Yet I do not wish to argue that the generic distinctions of romance and hagiography are collapsed in the Siege of Melayne, or for that matter in any other medieval romance, for such efforts have not met with success. Diana Childress has suggested that the overlap between romance and hagiography can be best understood by defining a new category of 'secular legend': 'From romance the secular legend borrows settings, style, and many story motifs ... But instead of entertaining their audiences ... the authors of the secular legends aim to teach moral lessons.' ${ }^{2}$ Andrea Hopkins has found, however, that this is not the case in a group of texts which she identifies as 'penitential romances.' Like Childress's 'secular legends', these romances feature a hero who 'does penance for his sinfulness or who may patiently undergo physical hardship and deprivation and who is rescued or rescues others by divine miracles'. ${ }^{3}$ Yet Hopkins concludes that these romances were not thought 'to constitute a fundamentally different kind of literature from other romances which do not deal with predominantly religious 
or didactic subject-matter'. The penitential romances are also found in conjunction with didactic penitential manuals, which 'suggests that the two types of composition were not seen as incompatible with each other, but instead answered different needs in their medieval readers'. ${ }^{4}$ The shared manuscript context of penitential manual and penitential romance illustrates the interdependence of two genres that, in modern scholarship, have too long been considered separately. Instead, as Jocelyn Wogan-Browne suggests, the overlap both of content and of audience in romance and hagiography should impel us not to dismiss these categories entirely, but rather to move 'beyond the modern literary-critical model of romance priority to a refocusing of romance and hagiography in their shared medieval contexts'. Such an effort requires that we look at the manuscripts in which these texts appear in order to find out how medieval writers and compilers identify the works, and to consider what such identification tells us about reading practices.

In the following pages, I will explicate the religious content of the Siege of Melayne, exploring how hagiographic, devotional, and eucharistic themes are used to depict a Christian community characterised by strength in the face of adversity, and wholeness in the face of efforts to fragment the community. The body of Turpin, the image of the crucified Christ, and the Host each represent the Corpus Christi, the body of Christ which stands for the community of Christian souls. ${ }^{6}$ What is peculiar about the Siege of Melayne, however, is that this community is not merely unified, but so full that it cannot accept any more members: here, incorporation in the body of Christ has a finite limit. In the poem, the wholeness of the body signifies both inclusion (of the Christians who are already its members) and exclusion (of the Saracen converts who might seek to join). Having outlined the religious content of the Siege of Melayne, I will suggest that it can be seen as representative of what one might call 'devotional romance' (that is, a chivalric narrative with pronounced spiritual or theological content), and will briefly compare some examples. While the category of 'devotional romance' may be useful to modern readers, it is nonetheless crucial to note that the manuscript context shows the extent to which medieval readers were unfettered by generic constraints. The combination and juxtaposition of texts within medieval manuscript collections illustrate the interpenetration of genres more than their distinct identity. As Paul Strohm has observed, while 'a concept of romaunce was generally shared and the term was used to classify and describe actual narratives', nonetheless 'the term is used in some strange ways', 
that is, used to identify texts which modern readers would not call 'romance'. ' I will conclude by showing that the Siege of Melayne, along with other texts in the same manuscript, illustrates the fluidity and variability of genre, which functions less as a consistent category than as an interpretive tool. Genre is, at least to some extent, not given by the writer but imposed by the reader, established not in a single creative moment but repeatedly, in a series of interpretive acts. ${ }^{8}$

The Siege of Melayne survives in a single manuscript dated to the mid-fifteenth century, known as the London Thornton manuscript (British Library, MS Additional 3 I042). John Thompson has given an exhaustive account of the manuscript's physical makeup and probable mode of production, with commentary on the significance of the combination and interrelation of texts in the manuscript. ${ }^{9}$ Since the Siege of Melayne survives in this single witness, and is not alluded to or cited elsewhere, ${ }^{\text {IO }}$ the poem itself is almost impossible to date. A lost Anglo-Norman original was posited by the text's first editor, Sidney Herrtage, at the suggestion of Gaston Paris. Though subsequent editors have repeated this assertion, no evidence of such an original has appeared. Herrtage dated the poem to the late fourteenth century, presumably on the basis of its relationship to the group of Ferumbras romances which he had also edited. ${ }^{\text {II }}$ Though the Siege of Melayne does not include the figure of Ferumbras, a converted Saracen of great physical and chivalric stature, Charlemagne appears in both works as the emperor at the head of the Christian army. The poem's more recent editors have dated the poem with comparable uncertainty: Mills and Shepherd c. I 400, Lupack, like Herrtage and Thompson, the second half of the fourteenth century. ${ }^{\text {I2 }}$ The poem's focus on the eucharist as a symbol not only of the Christian community but of the military host, and its emphasis on the inherence of the blood within the eucharistic host, supports a comparatively late date for the poem, when the debate regarding the simultaneous presence of both body and blood within the transubstantiated wafer was of increasing interest to lay readers - enough to merit clerical condemnation of the denial of concomitance in I4I 5 at the Council of Constance.

The religious context of the Siege of Melayne has long been noted. Childress observes that, in Archbishop Turpin, we find a hero who is more 'like a saint who endures prodigious physical torture'. ${ }^{13}$ The poem's latest editor, Shepherd, has drawn attention to a deeper level of theological engagement within the poem, agreeing with Barron that Turpin is 'something of a Christ figure' in the poem, and suggesting that the description of the desolate battlefield where Christian soldiers 
resort to drinking standing water stained with their own blood may 'reflect the imagery of the Crucifixion and the Eucharist'. ${ }^{14}$ For the purposes of this discussion, I will schematise the religious content of the Siege of Melayne as follows: the hagiographic, seen in the character of Turpin; the devotional, illustrated in the dramatic scene in the Sultan's chamber in which the crucifix, tortured by fire, miraculously refuses to burn; and the eucharistic, seen both directly, in the scene in which Turpin celebrates Mass for the weary troops before yet another battle, and indirectly, in the description of the bloodied (military) host itself. The wounds of Turpin, which increasingly become the focus of attention both within the narrative (for Charlemagne) and without (for the reader), serve to unify these disparate strands of religious content, so that the reader, like Charlemagne, becomes absorbed in the longed-for visual experience of Turpin's hidden wounds.

On one level, Turpin's depiction in the Siege of Melayne can be characterised as hagiographical; on another level, however, he appears to be both more than a saint and less. In keeping with earlier descriptions of Turpin (most famously in the Chanson de Roland), the Archbishop is a miles Christi in the fullest sense of the term: he throws himself into the heat of battle more passionately than any knight. While other nobles lead delegations of knights and soldiers, Turpin gathers around himself an army of priests; he has permission from the pope, says Turpin, to let them fight 'Bothe with schelde and spere' (6I9). Turpin seeks and receives permission to lead the vanguard, 'Assemble[d] undire my banere' (924). Turpin expresses his pastoral function in conventional terms, offering the sacrifice of the Mass on behalf of the disheartened troops (88I-9IO), but he also acts as a rather aggressive shepherd in urging the troops to action. He does not hesitate to apply the pastoral rod even to Charlemagne himself, when the emperor's resolve appears less than firm. Turpin accuses the hesitant emperor of heresy (673), and cries out, 'here I curse the, thou kynge! / Because thou lyffes in eresye / Thou ne dare noghte fyghte one Goddes enemy' (688-90). If the emperor does not apply himself wholeheartedly to the fight against the Saracens, declares Turpin, 'I sall stroye the, / Bryne and breke downn thi cité' (752-3). Threatened with utter destruction, both spiritual and physical, Charles gives in. The relentless devotion to God's will displayed by Turpin, together with his patient endurance of the wounds he repeatedly suffers in battle, contribute to the picture of Turpin as a warrior-saint. As Barron and Shepherd have observed, however, the specific nature of Turpin's wounds seem to hint at an even more exalted role: not merely warrior-saint, but figure 
of Christ. It might be argued that all saints are, in some sense, figures of Christ: what, after all, are the stigmata mysteriously acquired by some saints but the signs of the perfection of the saint's ability to mirror Jesus' suffering in the Crucifixion? Yet Turpin's wounds seem to point to a more specific identification:

The bischoppe es so woundede that tyde,

With a spere thoroweowte the syde,

That one his ribbis gan rese.

Thurgh the schelde and the browne bare,

A schaftemonde of his flesche he schare:

Lordynnges, this es no lese. (I3OI-6)

Turpin himself compares his own wound to Christ's; though I suffer 'A glafe thorowte my syde', says Turpin, 'Criste for me sufferde mare; / He askede no salve to his sare' (I345-7; cf. 70I-2). Turpin refuses not only salve for his wounds, but also food, drink, and even rest: 'I sall never ette ne drynke, / Ne with myn eghe slepe a wynke, / . . / To yone cité yolden bee' (I349-52). Turpin's protracted suffering is extended over 'dayes three' (I 579), evoking the period between the Crucifixion and the Resurrection.

One peculiarity of Turpin's behaviour detracts from the hagiographical motif so prominent in the general characterisation of the Archbishop: that is, the abuse he heaps upon the Virgin Mary. Following the news of the initial Christian defeat at Milan, Turpin throws down his staff and mitre, and rebukes the Mother of Jesus: 'A! Mary mylde, whare was thi myght, / That thou lete thi men thus to dede be dighte? / ... / Had thou noghte, Marye, yitt bene borne, / Ne had noghte oure gud men thus bene lorne: / The wyte is all in the' (5489, 554-6). The blame is all on you; strong words to apply to the Virgin, especially coming from a warrior-saint. On the one hand, Turpin's rebuke of Mary can be seen as simply a manifestation of the same zeal which causes Turpin to disregard secular authority (as opposed to the Virgin's divine authority) when he chastises Charles for cowardice and 'heresy'. On the other hand, as Mills has pointed out, Turpin's behaviour toward Mary associates him less with other heroic figures in the chansons de geste or medieval romances than with the enemy: the verbal rebuke of pagan gods, and even the physical destruction of their images, is a common scene in those texts. ${ }^{\text {Is }}$ As Mills puts it, 'here it is very difficult to avoid the feeling that he is being presented as a pagan'. ${ }^{6}$ It is important not to overemphasise the significance of Turpin's action 
toward Mary since, as Patrick Geary has shown, 'abuse' of the saints such as lowering an image in order to elicit more effective intercession on the part of the saint - was not an uncommon practice during the Middle Ages. ${ }^{17}$ Yet it is undeniable that Turpin stands out among other figures both in the Siege of Melayne and in comparable texts by virtue of the violence with which he pursues his single-minded devotion to the cause of God. ${ }^{18}$

The poem's most recent editor, Shepherd, has taken note of the 'crusading element' present in the work, that is, 'the militant Christianity, the belief in aggressive martial support for the Faith'. He points out that chronicles of the First Crusade feature men such as Peter Bartholomew, whose ecstatic visions served to fire up the spirits of the knights at Antioch. ${ }^{19}$ Even more strikingly similar to Turpin, however, is the behaviour of the priests attending their crusader flock at Antioch during the siege of I098. The earliest chroniclers of the First Crusade Fulcher of Chartres, Peter Tudebode, Raymond d'Aguilers, and the anonymous author of the Gesta Francorum - recount how the crusaders, tortured 'by cruel hunger' and simultaneously 'paralyzed by fear of the Turks', embarked upon 'three days of fasting' during which they purified themselves 'by confessing their sins ... by absolution, and by faithfully receiving communion of the body and blood of Christ'. ${ }^{20}$ In his account, Raymond d'Aguilers emphasises how these acts of devotion lifted up the spirits of the half-starved crusaders: 'So dejected were the Christians that father and son, brother and brother, exchanged neither salvation [greeting] nor glances as they passed on the streets. With the sudden change in spirit one could see the Christians go out as spirited horses, rattle their arms, wave their spears, and boisterously celebrate with acts and speeches. ${ }^{21}$ In his account of the siege of Antioch, written before I I 85 on the eve of the fall of Acre to Saladin during the Third Crusade, William of Tyre amplifies Raymond's account to accentuate both the devastating hunger of the crusaders and the devotion of the clergy attending them: 'the bodies of beasts which had died of suffocation or disease were dug up and devoured. Such were the foods by which they tried to quell the cravings of hunger and to prolong their miserable lives.' The famished people are heartened, however, first by the discovery of a miraculous relic and, second, by the ministrations of the priests who 'celebrated divine service in the churches and offered the sacrifice. They then invited the people ... to fortify themselves against the perils of the world by the body and blood of Christ.' William draws attention to the role of the clergy, who mingle with the troops 'clad in their 
sacerdotal robes and bearing in their hands the cross and the images of the saints', and singles out the Bishop of Puy who, in pressing the battle forward, 'was continually offering himself as a sacrifice for the Lord'. ${ }^{22}$ The Bishop, in William's account, both offers sacrifice (in the Mass) and is the sacrifice (in the battle). This is a double role that Turpin will also play in the Siege of Melayne.

The crusade chronicles also provide a rich background for the second aspect of the religious content of the poem, that is, the devotional. After the initial fall of Milan but before the aggressive assault on the city by Charlemagne's troops, a group of Christian knights, including Roland and Oliver, are captured and led to the chamber of the Sultan Arabas. There, they are privy to a miracle: the Sultan commands his men to 'feche one of theire goddis in, / And if he in this fire will byrne, / Alle other sett att noghte' (422-4). The crucifix is cast into the fire, heaped with 'bromstone' and 'pykke and terre' (458-9), yet it does not burn. In part, this miracle is a testimony to the devotion of Roland, who not only refuses the tempting offer of conversion made to him by Arabas (who mistakes Roland for Charlemagne himself), but bears witness to the Christian faith he fights for:

Goddis forbode and the holy Trynytee,

That ever Fraunce hethen were for mee,

And lese our Crysten laye!

For sothe, thou sowdane, trowe thou moste

One the Fader and the Sone and the Holy Goste,

Thire thre are alle in one. (406-I I)

As if in fulfilment of this testimony, the crucifix does not burn, but 'laye still ay as it were colde' (447); at last, the fire goes out, the crucifix emits a loud 'crake' (467), and 'A fire than fro the crosse gane frusche, / And in the Sarazene eghne it gaffe a dosche, / ... / That thay stode still als any stone' (470-3). The tormented crucifix becomes the tormentor, immobilising the Saracens so that 'Hanndis nore fete myghte thay stirre none' (474), making them vulnerable to the knights who then 'tuke the grete lordes with ire / And brynte tham in that bale fire' (488-9). In the test of fire, the Saracens lose every time.

Once again, comparable episodes are found in the earliest chronicles of the First Crusade, where the ordeal of fire is used by the Christians to test the veracity of Peter Bartholomew, who claims to have discovered a relic of the lance which was used to pierce Christ's side on the Cross. Raymond d'Aguilers recounts how Peter Bartholomew 
willingly walked through flames, carrying the lance, and emerged almost totally unscathed; for Raymond, this is proof of the relic's authenticity. ${ }^{23}$ Like the 'faire rode' (427) in the Siege of Melayne, the lance does not burn. A rather different manifestation of the ordeal of fire appears in Tudebode's account of the Crusade. He tells how the Christian knight Rainald is taken prisoner by the Saracen emir, who offers Rainald his life if he will only convert: 'Deny your God, whom you worship and believe, and accept Mohammed and our other gods. If you do so, we shall give you all that you desire.' Rainald refuses, falls on his knees, and bears witness to the authority of the Christian Trinity. So far, his story adumbrates that of Roland in the Siege of Melayne. But while in the latter text, Roland merely looks on as the crucifix is tested in the fire, Rainald pays for his faith with his life. The emir, 'in a towering rage because he could not make Rainald turn apostate', causes all the Christians within his grasp in Antioch to be stripped naked and bound together in a circle:

He then had chaff, firewood, and hay piled around them, and ... ordered them put to the torch. The Christians, those knights of Christ, shrieked and screamed so that their voices resounded in heaven to God for whose love their flesh and bones were cremated. ${ }^{24}$

In the Siege of Melayne, the appearance of the 'still' and 'colde' form of the crucifix (447) in place of the burning flesh of the faithful crusaders transforms what is (in Tudebode's account) a spiritual victory alone into a victory which is both spiritual and military. In the later text, it is the Saracen lords and not the Christian knights who are immobilised, 'still als any stone' (473), and burned in 'that bale fire' (489).

The treatment of the crucifix in the Siege of Melayne is peculiar in that the ordeal suffered by the object - remaining untouched in spite of being surrounded by burning brimstone and pitch - is less characteristic of the testing of images than it is of the testing of saints. Hagiographic texts repeatedly offer accounts of saints whose bodies, when subjected to torture, remain whole; which, when subjected to the flames, do not burn. ${ }^{25}$ The anthropomorphisation of the crucifix in the Siege of Melayne may be, in part, a consequence of its relationship to the account of the torment and death of the Christians in Antioch described by Tudebode. But, more importantly, the anthropomorphisation of the crucifix is part of a wider tendency in late medieval literature to emphasise the immanence of Christ's humanity, in devotional objects such as the crucifix and, especially, in the relic of 
Christ par excellence: that is, the eucharistic host. In this context, it is striking to note the resemblance of the behaviour of the crucifix in the Siege of Melayne to that of the host in the fifteenth-century Croxton Play of the Sacrament: like the crucifix in the earlier poem, the eucharist in the drama moves from being victim to tormentor. When the unscrupulous Jew Jonathas stabs the consecrated host, it bleeds, illustrating the reality of the transubstantiation the bread has undergone. The play thus dramatises the bleeding host miracles which were common in the later Middle Ages. ${ }^{26}$ Yet the bleeding host rapidly switches from victim to aggressor: when the panicking Jonathas tries to cast the host into a bubbling pot of oil, the host stubbornly sticks to his hand. Overcome by 'woodnesse', Jonathas attempts to drown himself and the host together; his fellows restrain him, and are compelled to cut the arm off in order to separate Jonathas from the host. When hand and host together are plunged into the boiling cauldron, 'All thys oyle waxyth redde as blood.' When in desperation the Jews finally seal the host in a hot oven, the oven itself bursts; blood streams out, and the image of the crucified Christ emerges to address the terrified sinner. ${ }^{27}$

The violence with which the host turns upon its tormentor in the Croxton Play of the Sacrament bears affinities to the destructive power which is deceptively latent in the 'still' and 'colde' crucifix in the Siege of Melayne. The violent 'crake' emitted by the rood, which renders its persecutors helpless, is echoed in the sound of 'the ovyn rave asunder and all tobrast' of the Croxton Play of the Sacrament. ${ }^{28}$ Yet the fate of the tormentor in each case is dramatically different: in the Croxton play, Jonathas and his fellows are moved by the sight of Christ, emerging from the sacrament itself, to convert to Christianity; in the Siege of Melayne, the sultan Arabas and his lords are utterly destroyed in body and in spirit. The difference between these two texts runs far deeper than generic distinctions. In the play, the content of the narrative is not merely didactic but also mimetic: the audience is impelled to undergo a kind of conversion analogous to that experienced by Jonathas. While they do not move from Judaism to Christianity, as Jonathas does, they too are led to turn towards Christ, and especially towards his actual bodily presence in the eucharist. In the siege poem, conversely, conversion is a non-issue. The sultan Arabas and his men are not accepted or even invited into the Christian community: their lot is death. Yet the sultan maintains a kind of immortality; not a personal immortality, but what might be called a categorical immortality. Arabas is dead, but 'the Sultan' continues to rule the Saracens and harry the Christians, for as soon as Arabas' death is known, 'the Sarazenes crouned sir Garsy' 
(49I). Without missing a beat, the interminable conflict of pagan wrong and Christian right marches on.

The exclusion of conversion in the Siege of Melayne distinguishes it sharply from the other Charlemagne romances conventionally associated with it. In texts of the Ferumbras group, following the model of the Old French Fierabras, the eponymous hero is the son of a Saracen ruler. Distinguished by his great stature and his feats of arms, Ferumbras presents himself as an eminently desirable recruit for the Christian side. He is led to convert by a combination of religious conviction and admiration for the Christian knights' chivalric accomplishments. In the Sowdone of Babylone, for example, an early fifteenth-century manifestation of the Ferumbras group, the Saracen champion bends to the authority of the sword as much as that of the Cross:

Hoo, Olyvere, I yelde me to the,

And here I become thy man.

I am so hurte I may not stonde;

I put me alle in thy grace.

My goddis ben false by water and londe;

I reneye hem alle here in this place.

Baptised nowe wole I be.

To Jhesu Crist I wole me take -

That Charles the Kinge shal sene -

And alle my goddes forsake. ${ }^{29}$

The juxtaposition of divine and feudal authority evident here - Ferumbras bowing down before Jesus Christ in the sight of 'Charles the Kinge' - is even more evident in Otuel and Roland, an early fourteenthcentury example of the Charlemagne romances. There, the Saracen knight Otuel couches his conversion in terms which even more vigorously conflate the divine and the feudal: when a white dove, embodiment of the Holy Spirit, alights upon him, Otuel declares, 'Mahoun and Iouyn, y wyl for-sake, / and to Jhesu crist y wyl me take, / to bene hys knyght. ${ }^{30}$ Ferumbras declares that he is henceforth Oliver's 'man', while Otuel pledges that he is Jesus' 'knyght'; in each case, however, the assumption of Christian identity is simultaneous with the acquisition of a place within the feudal system in which man owes loyalty to man.

Not so in the Siege of Melayne. Conversion appears at the outset of the narrative, only to be flatly rejected: the Sultan repeatedly requests that Charlemagne and his men 'torne and hethyn bee' (50; cf. 49-84, 390-408, I033-56). It is unsurprising that conversion from the Christian 


\section{2}

\section{Suzanne Conklin Akbari}

law to Saracen law is not an option; what is surprising, however, is that conversion from Saracen law to Christian law is also excluded. Such conversion is featured prominently in romances such as the Sowdone of Babylone and Otuel and Roland, as noted above, as well as in texts further afield, such as the early fourteenth-century King of Tars. ${ }^{3 \mathrm{I}}$ The unusual exclusion of conversion in the Siege of Melayne is the consequence of how the community is constituted within the text: the men led by Charlemagne (with helpful prodding by Turpin) are united by both religious and chivalric bonds. They are a military host ('oste', I 592) brought together by the eucharistic host ('oste', 89I), and while other romances emphasise the eagerness of the body of the Church to incorporate new members, in the Siege of Melayne, the boat is full. This community is full to overflowing; there is no room for anyone else.

This fullness is very much in evidence in the pivotal scene in which Turpin, in his priestly role, celebrates Mass for the assembled troops. It is clear that this eucharistic sacrifice is especially touched by grace, for Turpin finds the gifts of God upon the altar:

He blyssede the awtere with his hande,

And a fayre oste of brede therappon he fande,

That ever he sawe with syghte.

His chalesse was so full of wyne

There myghte no more hafe gone therin,

It come fro heven on highte. (890-5)

Turpin shares his knowledge regarding the sacred origin of these gifts, telling 'the hoste with lowde steven / How brede and wyne was sent fro heven' $(902-3)$. This experience energises Turpin who, full of 'egernesse', laughs out loud (9I3). The troops, too, are revivified by the Mass, following a pattern established in the chronicles of the First Crusade, as noted earlier. As priest, Turpin draws the community together through the sacrifice of the Mass; $;^{32}$ as warrior, Turpin draws them together by offering himself up as a sacrifice upon the battlefield, like such priestly heroes as the Bishop of Puy described by William of Tyre. The wounds he sustains are visible signs of the damage inflicted upon the crusaders by the Saracen enemy.

Yet Turpin's wounds are not simply a sign of vulnerability: like the bleeding wafer in the Croxton Play of the Sacrament that turns on its tormentor, like the crucifix surrounded by flames that destroys its persecutors in the earlier scene in the chamber of the sultan Arabas, the 
wounded body of Turpin proves to be the locus of an awful power. In the steadfastness with which he endures his wounds, refusing 'salve', 'mete' and 'drynke' (I I 88-90; cf. I 347-9), Turpin acts as an exemplar to the Christian troops who are also afflicted with grievous wounds, so much so that the entire field is covered with blood:

Bot one the morne the Cristen stode

A thowsande over theire fete in theire blode,

Of their awenn wondes wanne.

Othere refreschynge noghte many hade

Bot blody water of a slade,

That thurghe the oste ran. (I202-7)

This passage is resonant in two respects, evoking both the deprivation suffered by the knights of the First Crusade and the symbolic framework of the eucharist which provides the model for community formation. The anonymous author of the Gesta Francorum recounts how the crusaders at the castle of Xerigordo suffered from the lack of clean water:

Our men were therefore so terribly afflicted by thirst that they bled their horses and asses and drank the blood; others let down belts and clothes into a sewer and squeezed out the liquid into their mouths; others passed water into one another's cupped hands and drank; others dug up damp earth and lay down on their backs, piling the earth upon their chests because they were so dry with thirst. ${ }^{33}$

The abjection experienced by the crusaders at Xerigordo, driven to extreme uncleanliness and even a kind of self-interment, is transmuted in the Siege of Melayne into a moment of eucharistic union. Instead of the blood of unclean animals, the knights at Milan drink their own blood, which colours the stream bright red. The blood flowing through the military host mirrors the blood flowing through the eucharistic host in the sacrifice of the Mass. It is not abject but uplifting, a sign not of military vulnerability but of redemptive suffering.

At first glance, it may seem peculiar to find the eucharistic host characterised in terms of blood rather than bread. After all, in the words of the Fourth Lateran Council, Christ's 'body and blood are truly contained in the sacrament of the altar in the forms of the bread and the wine, the bread being transubstantiated into the body and the wine into the blood'. ${ }^{34}$ Yet even at the time of the Council in I2I5, 


\section{4}

\section{Suzanne Conklin Akbari}

theologians were engaged in defining the host as both blood and body of Christ. These speculations would become church doctrine exactly two hundred years later, when the Council of Constance declared that both body and blood were concomitant - that is, simultaneously present - in the host: 'let it be most firmly believed, without any doubt, that the whole body of Christ is truly contained in the form of the bread, as also in the form of the wine'. ${ }^{35}$ With this declaration of the real presence of both body and blood in each of the two manifestations of the sacrament, there could be no room to object that each communicant must partake of both bread and wine. The practice of withholding the chalice from the laity, which had begun in the twelfth century in response to concerns regarding the danger that the consecrated wine might be spilled, had by I4 I 5 acquired the authority of infallible doctrine. ${ }^{36}$ As the chalice was withheld, the wafer was accorded greater symbolic significance: it increasingly became the object of devotion, so that even the sight of the consecrated host was believed to afford spiritual benefits. ${ }^{37}$

Yet this is not to suggest that Christ's blood, previously understood to appear in the form of the wine, had come to be of lesser importance. Far from it: the late Middle Ages saw a flowering of devotion to the Passion which included, as a crucial element of the supplicant's affective response, a special focus on the blood flowing from the wounds of Christ. The early fourteenth-century mystic Richard Rolle, for example, uses the blood of Christ as a kind of repeated refrain to focus his contemplation:

Swet Jhesu, I thank the with al my hert for al that blode that thou so plenteuously bled in thy coronynge before al folke, when thy swet face was al on blode ... Here, swete Jhesu, I beseche the, weshe my soule with that blode, and enoynt and depeynt my soule and my mynd with that preciouse blode..$^{38}$

Rolle is representative of a widespread emphasis in late medieval piety on compassion, that is, literally sharing the passion of Christ. As Richard Kieckhefer puts it, such a response 'closed the distance' between the worshipper and God: 'identifying oneself with him, one suffered along with him and strove to partake in his sufferings'. ${ }^{39}$ Whether mediated through words or through images, the blood of Christ served as the means through which the individual soul could be united with God. Miracles of bleeding hosts served to remind the worshipper of the real presence of Jesus' body and blood, and hence to underline the impor- 
tance of both communion and the mere sight of the sacrament. Eamon Duffy quotes a popular lyric which plays on the liveliness of the host, the blood pulsing just below the surface:

Hyt semes quite, and is red

Hyt is quike, and seemes dede:

Hyt is flesche and seemes brede

Hyt is one and semes too;

Hyt is God body and no more..$^{40}$

The blood running through the host, invisible except in special moments of revelation, was a powerful reminder of the immanence of Christ, his hidden but immediate presence. Just so, in the Siege of Melayne, the bloody water which runs through the battlefield both witnesses to the suffering of the Christian knights and promises that their suffering will be redemptive, in imitation of the suffering of Christ himself. While the early twelfth-century chronicles of the First Crusade recount how the crusaders were stirred to action by the discovery of a sacred relic, the lance discovered by Peter Bartholomew, the troops at Milan are energised by something else: the very body of Christ, present in the eucharistic host of the Mass celebrated by Turpin; in the military host, spread out on a field flowing with their own blood mixed with water; and in the wounded body of Turpin, pierced in the side in imitation of his Saviour.

The wounds of Turpin become the focus of attention in the Siege of Melayne, as Charlemagne repeatedly begs him to remove the clothing which hides them. After the first injury, 'the kynge prayede the bischoppe fre / His wonde that he wolde late hym see, / That he hade tane in that fighte' (I $84-6$ ). Turpin refuses; after the next wound, Charles again asks, 'Fadir for Goddes are, / Thy woundes that thou walde late me see; / If any surgeoun myghte helpe thee, / My comforthe ware the mare' (1339-42). Finally, the only surviving manuscript of the poem breaks off just a few lines after Charlemagne, brought to tears by the sight of the suffering Turpin, laments 'the floure of presthode' who 'will no man his wondes late see' (I 584 , I 589). Turpin's withholding of the sight of his wounds serves two functions. Firstly, the refusal to uncover is also a refusal of medicine ('salve', I I 88, I 347) that might heal the wounds, and hence part of the overall vow of fasting that Turpin has undertaken. Secondly, the refusal to uncover keeps Charles and his knights in a state of tension: I will not eat or sleep, Turpin declares, until 'yone cité yolden bee, / Or 
ells therfore in batelle dye, / The sothe is noghte to hyde' (I $352-4$ ). Paradoxically, the hidden wounds of Turpin are a testimony to precisely that which is not hidden, and cannot be hidden: that is, "the sothe'. It is the very hidden nature of the wounds that guarantees their veracity, and their efficacy.

Charlemagne's desire to see the wounds of Turpin mimics the desire to see the wounds of Christ which appears in late medieval devotional texts such as The Prickynge of Love. There, the wound in Christ's side is the focus of tremendous longing, a breast to be sucked and a womb to be entered: the devout worshipper desires to be the very lance which entered Christ's body, rendered holy by its contact with the suffering flesh of the redeemer..$^{41}$ This moment of seeing the wounds was enacted liturgically in the elevation of the host, the crucial moment in the sequence of the Mass when the community of the faithful could look on and adore the newly transubstantiated sacrament. This practice, which began early in the twelfth century, became the focus of theological debate because it required that theologians specify precisely when the bread and wine were transubstantiated. Elevate the host a moment too early, and you incite the flock to idolatry; elevate it at the right moment, and you offer them the clearest sight of Christ they can hope for in this life. ${ }^{42}$ It is for this reason that the host is kept hidden until the words 'Hoc est corpus meum' are pronounced; the same suspense surrounds the body of Turpin in the Siege of Melayne. Like the consecrated eucharist, Turpin's body simultaneously displays and conceals the wounds of Christ. ${ }^{43}$

Miri Rubin has recently demonstrated that the symbol of the eucharist can function not just to include members of the community, generating a collective body, but also to exclude. Host desecration stories in particular, she argues, serve to delineate the boundaries which exclude Jews from the salvation of the New Law. ${ }^{44}$ This dynamic is very much in action in the Siege of Melayne which, unlike related romances of the Charlemagne group, forecloses the possibility of conversion and assimilation. This text is not about crossing boundaries but preserving them, both on the level of the individual body and on the level of the Christian community. Turpin vows to maintain the integrity of his body, abstaining from food, drink, salve and sleep; the Christian knights keep close watch on the besieged city of Milan, so that 'no Sarazene solde come owte' (I 5 I 4 ). In order to prevent them from 'isschuynge owte of the cité, / Kynge Charles with his menyé / Helde his batelle still' (I523-5). For the community as for the individual, nothing in and nothing out. 
Other medieval romances, while very different from the Siege of Melayne, also draw upon theological concepts in order to define the nature of the community depicted within the text; these can be loosely categorised as 'devotional romances'. In Otuel and Roland, for example, the Saracen Otuel is moved to convert not simply by the chivalric might of his opponent, Oliver, but by the hand of God: a white dove, symbol of the Holy Spirit, descends upon him, demonstrating in no hidden way the workings of providence in the course of the battle between pagan and Christian. The descent of the dove is, to Otuel, a sign to convert; to the Christian knights who are at war with the Saracens, it is a sign to accept Otuel as one of themselves. A theologically based notion of community is at work also in Richard Coer de Lion, where the king takes very seriously his role as head of the nation. His consumption of the flesh of dead Saracens is a grotesque parody of the priest's sacerdotal role: like the priest, Richard consumes body and blood on behalf of his community. Just as the sacrifice of the Mass, in the crusade accounts as in the Siege of Melayne, restores courage and aggression to the Christian knights, feasting on the Saracens restores Richard to his old leonine self and inspires his troops to destroy their enemy. ${ }^{45}$

Versions of both Otuel and Roland and Richard Coer de Lion are among those texts included, along with the unique copy of the Siege of Melayne, in the London Thornton manuscript. But this fact should not lead us to imagine that the similarities among these three texts that I have briefly sketched out above are the consequence of their presence in this compilation, that Robert Thornton is somehow responsible for skewing otherwise 'pure' romances toward a more didactic, explicitly Christian orientation. On the contrary, the presence of these poems in the London Thornton manuscript is a witness to the common nature of texts which may appear very dissimilar to us, both with regard to genre and with regard to subject matter. Modern readers persist in applying the name 'romance' to texts which prove to be too slippery to be confined by such generic constraints. This can be illustrated by reference to the London Thornton manuscript which, as Thompson has shown, contains a wide variety of material that can be classified as entertaining or didactic, lyric or romance. Modern readers typically identify 'four romances in this manuscript, The Siege of Jerusalem, The Sege of Melayne, The Romance of Duke Rowland and of Sir Ottuell of Spayne, and The Romance of Kyng Richard the Conqueroure'.$^{46}$ Yet the manuscript's medieval compiler would not (and did not) classify his texts in that way: Thornton does refer to Richard Coer de Lion and 
Rowland and Ottuell as romances, but he also titles an apocryphal account of the childhood of Jesus The Romance of Ypokrephum. When Finlayson, for example, notes the juxtaposition of Richard and the Ypokrephum in the London Thornton manuscript, he concludes that this simply 'suggest[s] that Richard was regarded as an edifying narrative'. ${ }^{47}$ More interestingly, I think, it suggests that, for the compiler, romance was a category that was not necessarily restricted to the deeds of knights.

What, then, could the compiler have intended by juxtaposing these two 'romances', one national in scope, one spiritual? In his analysis of the manuscript, Thompson notes that the incipit which calls the Ypokrephum a romance appears to have been added later by Thornton, and therefore may represent 'a determined effort ... to create in his reader's mind some limited sense of continuity, despite the unlikely pairing of the blood-thirsty Richard with a story about the childhood of Christ'.$^{48}$ But, as we have seen, this pairing is far from unlikely, for the model of community formation based on the presence of Christ's body in the sacrifice of the Mass serves as the model for community formation in devotional romances such as Richard Coer de Lion and the Siege of Melayne. Although it may seem strange to a modern reader to label an account of Christ's childhood a romance, evidently it was not strange to medieval readers. Further, it is worth noting that Thornton, unlike modern readers, does not identify the Siege of Melayne as a romance; like the Siege of Jerusalem, which appears immediately before it in the manuscript, it is identified as a 'sege' ${ }^{49}$ This might lead us to conclude that siege poems constitute a genre distinct from romance, or perhaps a sub-genre of romance: while, as Diane Speed has suggested, romances focus on the role of the hero as the focal point of his community or nation,,$^{50}$ siege poems stress instead the factors that threaten to tear the community apart. Shepherd has pointed out the affinities between the Siege of Melayne and the sixteenth-century Capystranus, both of which depict the pressures brought to bear on the Christian nation by the threat of pagan - in the Capystranus, Turkish - domination. ${ }^{51}$ In his study of Middle English siege poems, Malcolm Hebron argues that these works 'illustrate disasters of a magnitude which reveals the shape of history'. The siege is 'a purging experience, a painful rite of passage in which a great cultural or spiritual change is effected'. .2 $^{2}$

Yet I think it would be a mistake to label these sieges a separate genre, to create yet another category with which to divide and classify Middle English texts. Like Childress's 'secular legend', like Hopkins's 
'penitential romance', the siege poem is useful only as a provisional means of understanding how people in the Middle Ages organised their reading. If Thornton places the Siege of Jerusalem and the Siege of Melayne side by side, we ought to think about them in that way too; if Thornton pairs the 'romances' of Richard and Ypokrephum, we ought to do so as well, remembering that each collection of texts is itself an interpretive act. ${ }^{53}$ When, for example, the manuscript Harley 3954 juxtaposes the Ypokrephum with Mandeville's Travels, ${ }^{54}$ our response ought not to be 'What an unlikely combination!' Instead, we must ask what these texts might mean together: in this case, surely the solemn retracing of Jesus' steps, which is the very heart of the first half of Mandeville's Travels, is the link to the story of Ypokrephum, a narrative walk through Jesus' childhood. ${ }^{5 s}$

Now, it is certainly true that some 'unlikely combinations' are simply the result of happenstance: the compiler happens to have space in a manuscript booklet to accommodate a work of a certain length, and therefore includes it. Yet we need not assume that such is always the case. The manuscripts prepared by Robert Thornton are a remarkable example of late medieval compilation and reading practices that we are just beginning to understand. It is not the case, as has been said, that 'identifying the genre takes the first step toward a more complete understanding of these works $;{ }^{9}{ }^{5}$ rather, the first step is to recognise the fluidity of genre, its dependence upon manuscript context. ${ }^{57}$ Whether understood as romance or siege, hagiography or secular legend, the Siege of Melayne partakes of all these categories. Each context represents a different point of view; since the Siege of Melayne survives only in a single exemplar, it offers us the rare opportunity to see with the single eye.

\section{Notes}

Thanks to David Klausner and Fiona Somerset for their comments on an earlier draft of this essay.

W. R. J. Barron, English Medieval Romance (London, 1987), p. 97; on genre, see also pp. I-Io, 48-62. Mehl classifies the Siege of Melayne among the 'homiletic' romances, which 'occupy a position exactly in the middle between these two genres' of romance and hagiography (Dieter Mehl, The Middle English Romances of the Thirteenth and Fourteenth Centuries (London, I969), p. I2 I). Shepherd identifies it as a "generic "hybrid" in which 'the heroic and the hagiographic are combined' (Stephen H. A. Shepherd, "“This grete journee”: the Sege of Melayne', in Maldwyn Mills, 
Jennifer Fellows, and Carol M. Meale (eds), Romance in Medieval England (Cambridge, I99I), pp. II3-3I; quotations from pp. I I4, II6). See also Diana T. Childress, 'Between romance and legend: "secular hagiography” in Middle English literature', Philological Quarterly, 57 (I978), 3 I I-22, esp. p. 3 I6.

2 Childress, 'Between romance and legend', p. 3 I9.

3 Ibid., p. 320.

4 Andrea Hopkins, The Sinful Knights: A Study of Middle English Penitential Romances (Oxford, I990), p. I98.

5 Jocelyn Wogan-Browne, "'Bet ... to ... rede ... on holy seyntes lyves ...": romance and hagiography again', in Carol M. Meale (ed.), Readings in Middle English Romance (Cambridge, I994), pp. 83-97; quotation from p. 96.

6 On the body of Christ as symbol of community, see the seminal article of Mervyn James, 'Ritual, drama and social body in the late medieval English town', Past and Present, 98 (1983), 3-29; Miri Rubin, 'Small groups: identity and solidarity in the late Middle Ages', in Jennifer Kermode (ed.), Enterprise and Individuals in Fifteenth-Century England (Stroud, I99I), pp. I32-50; Miri Rubin, Charity and Community in Medieval Cambridge (Cambridge, 1987), 'Introduction'.

7 Paul Strohm, 'The origin and meaning of Middle English romaunce', Genre, Io (1977), I-28 (pp. I2-I3). See also Finlayson's effort to establish a 'suggested paradigm' of romance to which, however, 'many Middle English romances conform only imperfectly': John Finlayson, 'Definitions of Middle English romance', Chaucer Review, I5 (I980), I68-8 I (p. I79).

8 I owe this insight to Andrew Cole and Fiona Somerset.

9 John J. Thompson, Robert Thornton and the London Thornton Manuscript: British Library MS Additional 31042 (Cambridge, I987). For more on Thornton, see also John J. Thompson, 'Collecting Middle English romances and some related book-production activities in the later Middle Ages', in Mills, Fellows, and Meale (eds), Romance in Medieval England, pp. I7-38.

Io Shepherd notes a sixteenth-century allusion ('Journee', p. I I3 n. 4).

I I The Sege of Melayne, and the Romance of Duke Rowland and Sir Ottuell of Spayne, ... with ... the Song of Roland, ed. Sidney J. Herrtage, EETS e.s. 35 (London, I880, repr. Millwood, NY, I975), pp. x, xiii.

I2 Six Middle English Romances, ed. Maldwyn Mills, 2nd edn (London, I992), p. ix, n. 3; Middle English Romances, ed. Stephen H. A. Shepherd (New York and London, I995), p. 268n; Three Middle English Charlemagne Romances: The Sultan of Babylon, The Siege of Milan, and The Tale of Ralph the Collier, ed. Alan Lupack (Kalamazoo, I990), p. I05. None of the modern editions differ from Herrtage's edition in any significant way; line numbers and punctuation differ slightly. Quotations from the Siege of Melayne are based on Mills's edition and are cited parenthetically in the text.

I 3 Childress, 'Between romance and legend', p. 3 I6. 
I4 Shepherd, 'Journee', pp. I28, I29.

I5 Suzanne Conklin Akbari, 'Imagining Islam: the role of images in medieval depictions of Muslims', Scripta Mediterranea, I9-20 (I998-99), 9-27.

I6 Six Middle English Romances, ed. Mills, p. xiii.

I7 Patrick Geary, 'Humiliation of saints', in Stephen Wilson (ed.), Saints and their Cults: Studies in Religious Sociology, Folklore, and History (Cambridge, I983), pp. I23-40. Hardman similarly notes the resemblance of Turpin's rebuke of Mary and that seen in certain miracles of the Virgin; yet, as Hardman herself acknowledges, the Siege of Melayne differs from such texts in that the romance 'defers the satisfaction until later', that is, beyond the extant end of the romance. See Phillipa Hardman, 'The Sege of Melayne: a fifteenth-century reading', in Rosalind Field (ed.), Tradition and Transformation in Medieval Romance (Cambridge, I999), pp. 7I-86 (p. 82).

I 8 It is possible that the treatment of Mary in the text may also suggest a comparatively late date for the poem. Her intercessory role is referred to only in a negative sense, in Turpin's condemnation, which may reflect attitudes toward mediation (whether through images or through saints) during the last decade of the fourteenth century. (Here I disagree with Hardman's argument that the poem displays 'a devotion to the Virgin' ('Sege', p. 79).) Nicholas Watson has argued that the short text of Julian of Norwich's Revelation of Divine Love should be assigned a date after I 400 based on its reflection of contemporary attitudes toward images. See 'The composition of Julian of Norwich's Revelation of Divine Love', Speculum, 68 (I993), 637-83, esp. pp. 657-66.

I9 Shepherd, 'Journee', pp. I23, I26.

20 Peter Tudebode, Historia de Hierosolymitano Itinere, ed. and trans. John Hugh Hill and Laurita Hill (Philadelphia, I974), p. 85. See also Gesta Francorum et aliorum Hierosolimitanorum, ed. and trans. Rosalind Hill (London, I962), IX.28-9 (pp. 66-9).

2 I Raymond d'Aguilers, Historia Francorum Qui Ceperunt Iherusalem, ed. and trans. John Hugh Hill and Laurita Hill (Philadelphia, I968), p. 62.

22 William of Tyre, A History of the Deeds Done Beyond the Sea, ed. and trans. Emily Atwater Babcock and A. C. Krey, 2 vols (New York, I943), VI.7 (p. 27I), VI.I6 (pp. 285-6).

23 Raymond d'Aguilers, Historia Francorum, ed. Hill and Hill, pp. Ioo-I. Hill and Hill note that Raymond's account does not appear elsewhere and hence is at best 'suspect' (p. IOO n. I7).

24 Tudebode, Historia, ed. Hill and Hill, pp. 58, 59.

25 See Renate Blumenfeld-Kosinski and Timea Szell (eds), Images of Sainthood in Medieval Europe (Ithaca, I99I).

26 Megivern provides a table of bleeding host miracles which shows their preponderance during the fourteenth century; see James J. Megivern, Concomitance and Communion: A Study in Eucharistic Doctrine and Practice, Studia Friburgensia n.s. 33 (Fribourg and New York, I963), p. 44. On bleeding host miracles, see Peter Browe, Die eucharistischen Wunder des 
Mittelalters (Breslau, I938). For more selective accounts, see Miri Rubin, Corpus Christi: The Eucharist in Late Medieval Culture (Cambridge, I99I), pp. I2 I-8, and Eamon Duffy, The Stripping of the Altars: Traditional Religion in England c.1400-c.1580 (New Haven and London, I992), pp. I02-6. For a perceptive reading of the play in the context of such miracles, see Sarah Beckwith, 'Ritual, church, and theatre: medieval dramas of the sacramental body', in David Aers (ed.), Culture and History, 1350-160o: Essays on English Communities, Identities, and Writing (Detroit, I992), pp. 65-89.

27 Croxton Play of the Sacrament, in Non-Cycle Plays and Fragments, ed. Norman Davis, EETS s.s. I (Oxford, I970), lines 502, 674. On conversion in the play, see Donnalee Dox, 'Medieval drama as documentation: 'real presence' in the Croxton Conversion of Ser Jonathas the Jewe by the Myracle of the Blessed Sacrament', Theatre Survey, 38 (I997), 97-I I 5 . On the relationship of the play's antisemitism to contemporary attacks on Lollardy, see Lisa Lampert, 'The once and future Jew: the Croxton Play of the Sacrament, little Robert of Bury, and historical memory', Jewish History, I5 (200I), 235-55.

28 Croxton Play of the Sacrament, in Non-Cycle Plays, ed. Davis, line 943.

29 The Sowdone of Babylone, in The Romaunce of the Sowdone of Babylone and of Ferumbras his Sone who conquerede Rome, ed. Emil Hausknecht, EETS e.s. 38 (London, I88 I, repr. Oxford, I969), lines I353-62. I follow the punctuation used in Lupack, ed., Three Middle English Charlemagne Romances.

30 Otuel and Roland, lines 575-7, in Firumbras and Otuel and Roland, ed. Mary Isabelle O’Sullivan, EETS o.s. I98 (London, I935).

3 I The King of Tars, ed. Judith Perryman (Heidelberg, I980); conversion scene at lines $877-936$.

32 On the priest's role, see John Bossy, 'The Mass as a social institution', Past and Present, Ioo (I983), 29-6I.

33 Gesta Francorum, ed. Hill, I. 2 (pp. 2-5).

34 '[C]orpus et sanguis in sacramento altaris sub speciebus panis et vini veraciter continentur; transubstantiatis, pane in corpus, et vino in sanguinem.' Concilium Laterensae IV, chapter I, in Sacrorum Conciliorum nova, et amplissima collectio, ed. J. D. Mansi, 3 I vols (Venice, I759-93), vol. 22, cols $98 \mathrm{I}-2$. On eucharistic theology up to the Fourth Lateran Council, see Gary Macy, The Theologies of the Eucharist in the Early Scholastic Period: A Study of the Salvific Function of the Sacrament according to the Theologians c. 1080-c.1220 (Oxford, I984).

35 '[C]um firmissime credendum sit et nullatenus dubitandum, integrum Christi corpus et sanguinem tam sub specie panis, quam sub specie vini veraciter contineri.' Concilium Constantiense generale, in Sacrorum Conciliorum collectio, ed. Mansi, vol. 27, col. $727 \mathrm{~d}$.

36 On the 'danger' [periculum] of spilling expressed by medieval theologians, see Megivern, pp. 240-I; quotation (from Aquinas) on p. $22 \mathrm{I}$.

37 Duffy, Stripping of the Altars, pp. 95-I I6.

38 Richard Rolle, 'Meditation B', lines $266-72$ in Richard Rolle: Prose and 
Verse, ed. S. J. Ogilvie-Thomson, EETS 293 (Oxford, I988), p. 75. On Rolle, see Nicholas Watson, Richard Rolle and the Invention of Authority, Cambridge Studies in Medieval Literature I3 (Cambridge, I99I).

39 Richard Kieckhefer, Unquiet Souls: Fourteenth-Century Saints and Their Religious Milieu (Chicago, I984), pp. 89-I2I; quotation from p. I05. On the blood of Christ in early modern devotion, see J. T. Rhodes, 'The body of Christ in English eucharistic devotion, c. I500-c. I620', in Richard Beadle and A. J. Piper (eds), New Science Out of Old Books: Studies in Manuscripts and Early Printed Books in Honour of A. I. Doyle (Aldershot, I995), pp. 388-4I9.

40 Rossell Hope Robbins, 'Popular prayers in Middle English verse', Modern Philology, 36 (1939), 337-56 (p. 344); noted in Duffy, Stripping of the Altars, p. I02.

4I The Prickynge of Love, ed. Harold Kane, Salzburg Studies in English Literature, Elizabethan and Renaissance Studies 91: io (Salzburg, I983), pp. 9-IO, I2. See the perceptive discussion of this text in Sarah Beckwith, Christ's Body: Identity, Culture and Society in Late Medieval Writings (London and New York, I993), pp. 56-62.

42 See V. L. Kennedy, 'The moment of consecration and the elevation of the Host', Mediaeval Studies, 6 (I944), I2 I-50; Rubin, Corpus Christi, pp. $55-8$.

43 On the sight of Christ's wounds in the host, see Rubin, Corpus Christi, pp. 302-6.

44 Miri Rubin, Gentile Tales: The Narrative Assault on Late Medieval Jews (New Haven and London, I999).

45 Text in Der mittelenglische Versroman über Richard Löwenherz, ed. Karl Brunner, Wiener Beiträge zur Englischen Philologie 42 (Vienna, I9I3). On the eucharistic symbolism, see Suzanne Conklin Akbari, 'The hunger for national identity in Richard Coer de Lion', in Robert Stein and Sandra Pierson Prior (eds), Reading Medieval Culture (Notre Dame, 2004).

46 E.g. Finlayson, 'Definitions of Middle English romance' (n. 7 above), I64; cf. Hardman, 'Sege of Melayne' (n. I7 above), p. 72.

47 Finlayson, 'Definitions', p. I65.

48 Thompson, Robert Thornton (n. 9 above), p. 48.

49 On the deliberate juxtaposition of these siege poems in the manuscript, see Thompson, Robert Thornton, p. 48. For an extended analysis of the Siege of Jerusalem, see Bonnie Millar, The Siege of Jerusalem in its Physical, Literary, and Historical Contexts (Dublin, 2000). A new edition of the poem is promised by David Lawton and Ralph Hanna III; until then, see The Siege of Jerusalem, ed. E. Kölbing and Mabel Day, EETS o.s. I 88 (London, I932).

50 Diane Speed, 'The construction of the nation in Medieval English romance', in Meale (ed.), Readings in Medieval English Romance (n. 5 above), pp. I $35-57$, esp. pp. I46-7.

5I Shepherd, 'Journee', p. I2I; Shepherd prints an edition of the Capystranus 


\section{Suzanne Conklin Akbari}

in his Middle English Romance (pp. 388-408). See also Malcolm Hebron, The Medieval Siege: Theme and Image in Middle English Romance (Oxford, I997), pp. 84-90.

52 Hebron, Medieval Siege, p. I35.

53 Phillipa Hardman offers a sensitive reading of the Siege of Melayne in the context of the Marian poem 'O florum flos' which follows it in the London Thornton manuscript, though her extended argument - 'that the end of the romance involved a miracle of some kind in which Mary intervened in the course of events on behalf of her knights' - is less persuasive. See Hardman, 'Sege', pp. 82-4 (pp. 82-3). On the sequence of texts in the manuscript, see also her 'Reading the spaces: pictorial intentions in the Thornton manuscripts, Lincoln Cathedral 9I and BL MS Add. 3 IO42', Medium Aevum, 63 (I994), 250-74.

54 Noted in Thompson, Robert Thornton, p. 48 n. 25.

55 Middleton points out that the potentially jarring presence of Piers Plowman along with Mandeville's Travels can be attributed to the coherency of the Vernon manuscript and its overall focus on conversion: 'It is a book about the peoples of the Book in their temporal and spiritual establishments.' Anne Middleton, 'The audience and public of Piers Plowman', in David Lawton (ed.), Middle English Alliterative Poetry and its Literary Background (Cambridge, I982), pp. IOI-23 (p. I06).

56 Childress, 'Between romance and legend', p. 320.

57 On manuscript compilation practices, see Ralph Hanna III, Pursuing History: Middle English Manuscripts and Their Texts (Stanford, I996), pp. $2 \mathrm{I}-34$. 